\title{
Jurnal Muara
}

\section{Sains, Teknologi, Kedokteran, dan Ilmu Kesehatan}

Volume 2, Nomor 2, Oktober 2018

\section{Kata Pengantar}

Redaksi Jurnal Muara terbit sebagai wadah publikasi bagi para peneliti dari dalam Untar maupun luar Untar. Jurnal Muara Sains, Teknologi, Kedokteran dan Ilmu Kesehatan (JMSTKIK) terbitan volume 2 nomor 2 bulan Oktober 2018, merupakan terbitan yang keempat sejak pelaksanaan Seminar Nasional Riset Multidisiplin (SNRM) 2017 yang diselenggarakan oleh Direktorat Penelitian dan Pengabdian kepada Masyarakat Universitas Tarumanagara. Tulisan hasil pelaksanaan SNRM yang telah mendapatkan masukan dari para pendengar dan Reviewer selanjutnya diterbitkan dalam Jurnal Muara sesuai dengan kelompok bidang Ilmu Sains, Teknologi, Kedokteran dan Ilmu Kesehatan.

Pada terbitan Jurnal Muara JMSTKIK volume 2 nomor 2 bulan Oktober 2018 yang terbit ini, lebih banyak manuskip yang masuk melalui Open Journal Systems yang diterima oleh redaksi yang diproses review untuk diperbaiki dan diterbitkan. Hanya artikel yang telah melalui proses tersebut dan layak yang terbit dalam JMSTKIK ini.

Penerbitan JMSTKIK merupakan salah satu dari 3 serangkaian jurnal terbitan Direktorat Penelitian dan Pengabdian kepada Masyarakat Universitas Tarumanagara dengan fokus kelompok ilmu yang berbeda. Pada terbitan JMSTKIK ini, terdapat beberapa artikel dengan topik bidang ilmu kedokteran dan ilmu kesehatan seperti: gizi, kesehatan ibu dan anak, penyakit degeneratif, kesehatan reproduksi wanita, dan genetik. Dalam topik ilmu sains dan teknologi, seperti: bidang ilmu teknik sipil, perencanaan berbasis komunitas pada kawasan pasca bencana, dan transformasi -adaptasi pemanfaatan ruang kota.

Kami mengucapkan terima kasih untuk kelancaran penerbitan Jurnal ini kepada tim editor yang telah membantu menjaga proses penerbitan jurnal ini terus berjalan. Penghargaan juga kami sampaikan kepada para Reviewer yang telah berkenan memberikan masukan yang berharga, memberikan saran perbaikan untuk menjaga kualitas jurnal. Terima kasih juga kami sampaikan kepada Rektor Universitas Tarumanagara dan Direktur Penelitian dan Pengabdian kepada Masyarakat untuk dukungan dan fasilitasnya sehingga JMSTKIK volume 2 nomor 2 bulan Oktober 2018ini terbit.

Kami berharap jurnal ini dapat bermanfaat untuk diseminasi dan pengembangan keilmuan bagi peningkatan kualitas para akademisi dan peneliti, serta memperkaya pengetahuan dalam bidang ilmu Sains, Teknologi, Kedokteran dan Ilmu Kesehatan. Secara berkelanjutan juga kami terus berupaya untuk meningkatkan kualitas JMSTKIK ini untuk kemajuan bersama.

Jakarta, 30 Oktober 2018

Redaksi Jurnal Muara Ilmu Sains, Teknologi, Kedokteran dan Ilmu Kesehatan 